\title{
Opinie położnych na temat planowanego porodu odbywanego w warunkach pozaszpitalnych*
}

\author{
Opinions of midwives on the planned out-of-hospital birth setting
}

\author{
Dorota Fryc ${ }^{1 凶}$, Anna Bielicka², Dorota Ćwiek¹, Katarzyna Szymoniak', Agata Daszkiewicz ${ }^{1}$ \\ ${ }^{1}$ Pomorski Uniwersytet Medyczny w Szczecinie, Samodzielna Pracownia Umiejętności Położniczych, ul. Żołnierska 48, 71-210 Szczecin \\ Pomeranian Medical University in Szczecin, Independent Laboratory of Obstetrics \\ ${ }^{2}$ Samodzielny Publiczny Zakład Opieki Zdrowotnej Ministerstwa Spraw Wewnętrznych i Administracji, ul. Jagiellońska 44, 70-382 Szczecin \\ Independent Public \\ $\triangle$ porodydomowe@gmail.com
}

\begin{abstract}
Introduction: According to the Nurses and Midwives Act and other legal Acts, a midwife is a person having appropriate competence for independent care of a woman during physiological pregnancy, childbirth and the postpartum period, and a newborn. These entitlements do not only apply to practice in a hospital or clinic, but also to home conditions, including physiological delivery in locations other than a hospital.

The aim of the study is to know the opinion of midwives on planned births in non-hospital locations.

Materials and methods: 233 midwives from all over Poland were surveyed. The survey was conducted between May and
\end{abstract}

\begin{abstract}
ABSTRAKT
Wstęp: Według ustawy o zawodach pielęgniarki i położnej oraz innych wykonawczych aktów prawnych polska położna jest osobą mającą odpowiednie kompetencje do samodzielnej opieki nad kobietą podczas fizjologicznej ciąży, porodu i połogu oraz nad noworodkiem. Uprawnienia te swoją mocą obejmują nie tylko praktykowanie w warunkach szpitalnych, ale również w środowisku domowym kobiety. Dotyczy to także przyjęcia porodu fizjologicznego w miejscach alternatywnych dla szpitala. Celem pracy było poznanie opinii położnych na temat planowanego porodu, prowadzonego samodzielnie przez położną w warunkach pozaszpitalnych.

Materiały i metody: Badaniem objęto 233 położne z całej Polski. Sondaż prowadzony był w okresie od maja do sierpnia 2014 r.
\end{abstract}

August 2014. The diagnostic survey method was applied using the author's questionnaire. Statistica 10 and MS Office programs were used for statistical analysis.

Results: $\mathbf{2 2 . 1 \%}$ of the surveyed midwives expressed a willingness to attend a home birth. $67.1 \%$ of respondents would not attend a home birth. The decision to attend a birth in non-clinical setting was significantly dependent on the safety of such a birth $(\mathrm{p}=0.0000)$.

Conclusions: There was a statistically significant relationship between the opinion of the respondents on the safety of outof-hospital birth setting and possible handling of such labors. Keywords: home birth; midwife; independent practice.

\section{WSTĘP}

W ciągu wieków transformacjom podlegały różne uwarunkowania praktykowania w zawodzie położnej. Dzisiejsze ramy tej profesji na obszarze Unii Europejskiej - również na obszarze Polski - wyznaczają kierunki działania przedstawicieli
Skorzystano z metody sondażu diagnostycznego z zastosowaniem autorskiego kwestionariusza ankiety. Do analizy statystycznej wykorzystano programy Statistica 10 oraz MS Office. Wyniki: Chęć prowadzenia porodu domowego wyraziło 22,1\% badanych położnych. Prowadzenia porodu w domu nie podjęłoby się $67,1 \%$ respondentek. Decyzja o przyjęciu porodu w warunkach pozaszpitalnych była istotnie zależna od opinii o bezpieczeństwie $(\mathrm{p}=0,0000)$.

Wnioski: Zaistniała istotna statystycznie zależność między opinią ankietowanych na temat bezpieczeństwa porodu w warunkach poza szpitalnych a ewentualnym zajmowaniem się takimi porodami.

Słowa kluczowe: poród domowy; położna; samodzielność zawodowa.

\footnotetext{
*Artykuł na podstawie pracy magisterskiej Anny Darii Bielickiej pt. „Opinie położnych na temat planowanego porodu odbywanego w warunkach pozaszpitalnych” (promotor: dr n.zdr. Dorota Fryc, recenzent: dr hab. n. med. prof. Agnieszka Brodowska, oryginał obejmuje: 127 stron, 34 ryciny, 23 tabele, 78 pozycji piśmiennictwa) oraz pracy doktorskiej Doroty Fryc pt. „Kompetencje zawodowe położnych w świetle ustaw i rozporządzeń polskich. Zapotrzebowanie społeczne na opiekę okołoporodową sprawowaną przez położne" (promotor: dr hab. n. med. prof. Jacek Rudnicki, recenzenci: prof. dr hab. n. zdr. Beata Karakiewicz, prof. dr hab. n. med. Ewa Dmoch-Gajzlerska, oryginał obejmuje: 271 stron, 53 ryciny, 108 tabel, 121 pozycji piśmiennictwa).
}

tego zawodu. W okresie międzywojennym i w latach 50-60. $\mathrm{XX}$ w. poród w domu lub w izbie porodowej był zjawiskiem powszechnym i akceptowanym. W państwowym systemie ochrony zdrowia funkcjonowało stanowisko położnej miejskiej, której zadaniem w rejonie jej praktykowania było przede wszystkim przyjmowanie porodów domowych. Najwięcej 
porodów w warunkach domowych odbywało się w latach 50. i 60. XX w. Również popularnym miejscem porodu były izby porodowe. Położne, prowadzące samodzielnie placówki opieki zdrowotnej w formie Izb Porodowych, miały ogromną wiedzę i samodzielność [1]. Jeszcze w 1950 r. w Polsce było 2500 izb porodowych. Liczba tych miejsc zmniejszała się wraz z tendencją do przenoszenia fizjologicznych porodów do szpitali, ograniczania kompetencji położnych i systemową zmianą świadomości społecznej w tej dziedzinie [2].

Lata 70. i następne poprzedniego stulecia zaowocowały systemowym wyeliminowaniem porodu pozaszpitalnego jako bezpiecznego miejsca urodzenia dziecka, a także jako sposobu wykonywania zawodu położnej [3]. Do 1996 r. nie było aktu prawnego określającego zakres kompetencji położnych. Nieliczne położne, które praktykowały w owym czasie samodzielnie, robiły to na podstawie przedwojennej ustawy dotyczącej zawodu położnej z 16.03.1928 r. [4]. W okresie przemian politycznych w kraju zmiany dotykały różnych grup zawodowych, w tym grupy zawodowej położnych. Uchwalono w $1996 \mathrm{r}$. ustawę zawodową dla pielęgniarek i położnych (Dz.U. $2001 \mathrm{nr}$ 57, poz. 602 z późniejszymi zmianami). Był to początek zmian dla zawodu położnej i trudny start do ponownej emancypacji zawodowej.

Zawód położnej wg polskiego prawa jest samodzielnym zawodem medycznym [5]. Jeżeli jest mowa o samodzielności oraz autonomii zawodu, powinno być także oczywiste, że nie ma takiej profesji, która mogłaby kontrolować dany zawód lub z nim konkurować [6]. Położna wykonująca swój zawód pełni funkcję profilaktyczną, wychowawczą, opiekuńczą, terapeutyczną oraz rehabilitacyjną, poza tym funkcję naukowo-badawczą, promocji zdrowia i zarządzania. Na podstawie specjalistycznych kwalifikacji, braku ingerencji w niezależność, w stosowanie metod działania, nieskrępowane prawnie praktykowanie oraz relacje pomiędzy położną a podopieczną opartą na zaufaniu uznano zawód położnej za wolną profesję [7].

Jednym ze sposobów praktykowania w zawodzie położnej jest opieka nad kobieta rodzącą w jej środowisku domowym. Standardy opieki okołoporodowej (SOO), mające rangę aktu prawnego, wskazują na położną jako jednego z profesjonalistów uprawnionych do prowadzenia fizjologicznego porodu poza szpitalem, przyznając również kobiecie prawo wyboru miejsca porodu [8]. W związku z postępującą medykalizacją aktu porodu należałoby zdefiniować, jak przebiega poród fizjologiczny/naturalny. Według Światowej Organizacji Zdrowia (WHO) „Poród normalny zaczyna się w sposób spontaniczny, niskie ryzyko występuje na początku i utrzymuje się do końca porodu. Dziecko rodzi się z położenia podłużnego główkowego, pomiędzy 37. a 42. tygodniem ciąży. Po porodzie matka i dziecko są w dobrym stanie zdrowia" [9]. Zgodnie z Europejską Siecią Stowarzyszeń na Rzecz Narodzin (European Network of Childbirth Assocations) „Poród normalny rozpoczyna się samoistnie, urodzenie dziecka i łożyska odbywa się w czasie specyficznym dla każdej kobiety i dzięki jej wysiłkowi, a dziecko po urodzeniu pozostaje przy matce. Interwencje medyczne, takie jak sztuczne przebicie pęcherza płodowego, wywołanie lub przyspieszenie porodu, znieczulenie i nacięcie krocza, nie powinny być stosowane rutynowo ani traktowane jako składowa porodu normalnego" [10]. Brytyjska narodowa publiczna służba zdrowia wraz z National Institute for Health and Care Excellencez wydały w 2014 r. oświadczenie dotyczące zalecanego miejsca porodu w przypadku ciąży fizjologicznej. Obie te instytucje zalecają odbycie porodu poza murami szpitala aż 45\% kobiet w ciąży niskiego ryzyka. Wskazują także na położne jako profesjonalistów medycznych, dzięki którym zmniejsza się liczba zbędnych interwencji medycznych. Zalecenia te zostały wydane na podstawie badań [10].

Tymiński [11] zastanawia się nad przyznaną przez polskiego ustawodawcę możliwością prowadzenia samodzielnie przez położną fizjologicznego porodu. Rozważania Tymińskiego prowadzone są nad istotą porodu. Autor zauważa, że obecnie poród nie jest tylko czynnością fizjologiczną, lecz skomplikowaną procedurą medyczną. Zdaniem Tymińskiego jest też tak interpretowany przez prawo. Tymiński pyta więc, kto może udzielać specjalistycznych okołoporodowych procedur medycznych. Czy położna? Rozważania te prowadzone są na poziomie zdefiniowania istoty porodu fizjologicznego, ale czy osobniczą fizjologię kobiety może i powinno definiować prawo? Czy raczej opieka w tym szczególnym momencie życia nie powinna być zindywidualizowana i holistyczna?

W Polsce poród w warunkach domowych jest prawnie usankcjonowany. Pomimo to odbycie porodu w domu traktowane jest niemal jak proceder i nagminnie kryminalizowane. Większość danych liczbowych dotyczących porodów poza szpitalem łączy wyniki pochodzące z planowanych porodów w warunkach pozaszpitalnych przy asyście doświadczonej położnej z porodami nagłymi, przypadkowymi, w tym porodami u kobiet w ciąży wysokiego ryzyka. Prowadzi to do powstania mylnego obrazu bezpieczeństwa porodu oraz wprowadza niejasność co do umiejętności, odpowiedzialności i kompetencji położnych. Poza tym w samym środowisku położnych pojawiają się wątpliwości dotyczące słuszności istnienia prawnych umocowań odbycia porodu w alternatywnym miejscu. Te same wątpliwości przeżywa kobieta spodziewająca się dziecka i rozważająca wybór domu jako miejsca urodzenia swojego potomka. Dodatkowo media epatują strasznymi opowieściami o szpitalnych niepowodzeniach położniczych, nie równoważąc ich pozytywnymi obrazami, których statystycznie jest dużo więcej. Wszyscy zainteresowani tematem otrzymują dualistyczny przekaz, na podstawie którego trudno o obiektywny, własny ogląd i merytoryczną dyskusję.

Celem badań było m.in. poznanie opinii położnych na temat prowadzenia planowanego porodu poza szpitalem.

\section{MATERIAŁY I METODY}

Badaniem objęto 233 położne z całej Polski. Sondaż prowadzony był w okresie od maja do sierpnia 2014 r. Dobór grupy badanej był przypadkowy, a udział w badaniu dobrowolny i anonimowy. Skorzystano z metody sondażu diagnostycznego z zastosowaniem autorskiego kwestionariusza ankiety, zawierającego 34 pytania typu zamkniętego i otwartego $\mathrm{w}$ formie 
elektronicznej oraz papierowej. Pytania zawarte w ankiecie dotyczyły kwalifikacji, samodzielności zawodowej położnych i porodów w warunkach pozaszpitalnych.

Do analizy statystycznej wykorzystano program Statistica 10 oraz MS Office.

\section{WYNIKI}

W badaniu wzięły udział 233 położne - same kobiety - w wieku 20-71 lat. Wśród nich najliczniejszą grupę tworzyły ankietowane w wieku 20-29 (43,3\%) i 40-49 (28,8\%). Staż pracy respondentek mieścił się $w$ granicach od $<2$ do >30 lat. Najwięcej położnych pracowało mniej niż 2 lata (25,75\%), a najmniej powyżej 30 lat (4,72\%); 9,44\% nie pracowało jeszcze nigdy w zawodzie. Na sali porodowej pracowało 48,1\% respondentek, w tym $48,2 \%$ robiło to w dalszym ciągu. Najwięcej położnych $(61,4 \%)$ pracowało w szpitalu, w niepublicznych zakładach opieki zdrowotnej $-13,7 \%$, indywidualną praktykę w miejscu wezwania deklarowało 4,7\%. Praktykę grupową położniczą wykonywało 1,3\%. Dom Narodzin jako miejsce pracy wskazało 0,4\% respondentek, tyle samo badanych 0,4\% deklarowało praktykę w izbie porodowej. Własny gabinet posiadało 2,6\% położnych, inne miejsce pracy położnych stanowiło 17,6\%. W badanej grupie znajdowało się $20,2 \%$ położnych dyplomowanych, 38,6\% miało tytuł licencjata położnictwa, 39,9\% respondentów było magistrami położnictwa/pielęgniarstwa. W trakcie studiów II $^{\circ}$ na kierunku położnictwo było 11,2\%, a 1,3\% na studiach położniczych pomostowych. Inne wykształcenie miało 6\%. Wśród respondentek 44,2\% ukończyło dodatkowe kursy/specjalizacje.

Położne biorące udział w sondażu były mieszkankami wszystkich województw Polski i praktykowały w różnych częściach kraju (ryc. 1).

Większość (92,3\%) położnych twierdziła, że w Polsce porody w warunkach pozaszpitalnych są legalne, 3,4\% twierdziło, że nie, a 4,3\%, że nie są legalne, lecz mimo to odbywają się.

Położne zapytano o ich opinię na temat bezpieczeństwa porodu w warunkach pozaszpitalnych. Odpowiedzi na to pytanie przedstawiono na rycinie 2 . Odpowiedzi na pytania były istotnie zależne od wieku respondentek $\left(\chi^{2}=24,82 ; \mathrm{p}=0,015\right)$.

Respondentki zapytano także, czy podjęłyby się prowadzenia porodu w warunkach pozaszpitalnych. Odpowiedzi przedstawiono na rycinie 3 .

Częstość odpowiedzi była istotnie zależna od wieku respondentek $\left(\chi^{2}=38,19 ; p=0,003\right)$, stażu pracy $\left(\chi^{2}=80,9\right.$; $p=0,000)$ oraz stażu pracy na sali porodowej $\left(\chi^{2}=50,74\right.$; $\mathrm{p}=0,000)$. Zależała także od opinii na temat bezpieczeństwa porodu w warunkach pozaszpitalnych $\left(\chi^{2}=126,26\right.$; $\left.p=0,000\right)$, uczestnictwa $\mathrm{w}$ takim porodzie $\left(\chi^{2}=239,37 ; \mathrm{p}=0,000\right)$ oraz znajomości położnej przyjmującej porody domowe $\left(\chi^{2}=50,59\right.$; $\mathrm{p}=0,000)$.

Respondentki odpowiadały także na pytanie dotyczące koniecznych zmian, które zachęciłyby środowisko położnych do prowadzenia porodów w warunkach pozaszpitalnych (ryc. 4).

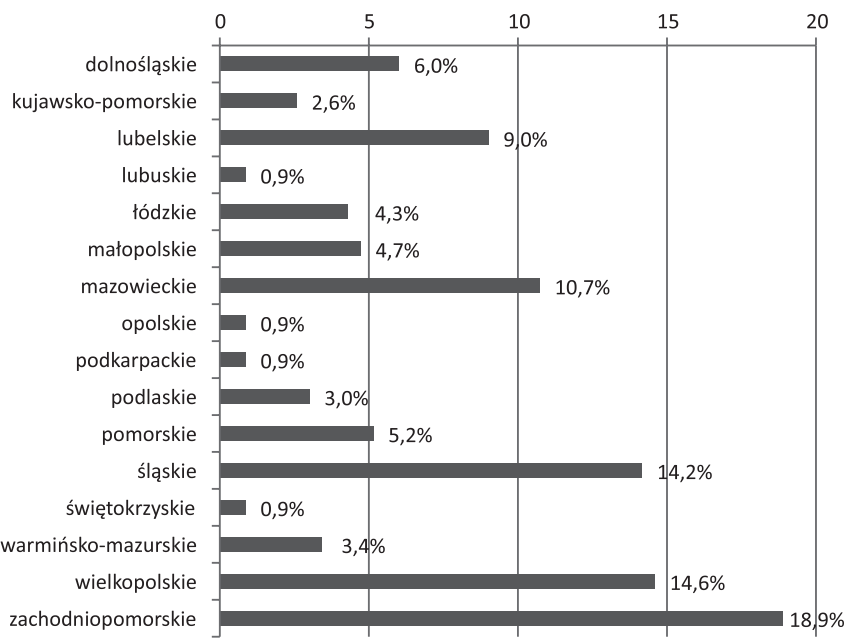

RYCINA 1. Województwo pracy respondentów

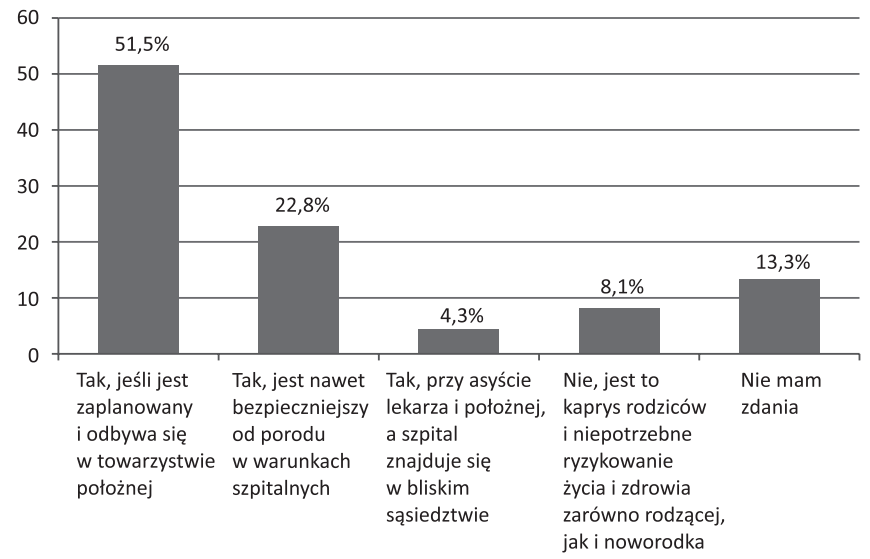

RYCINA 2. Bezpieczeństwo porodu w alternatywnych do szpitala miejscach

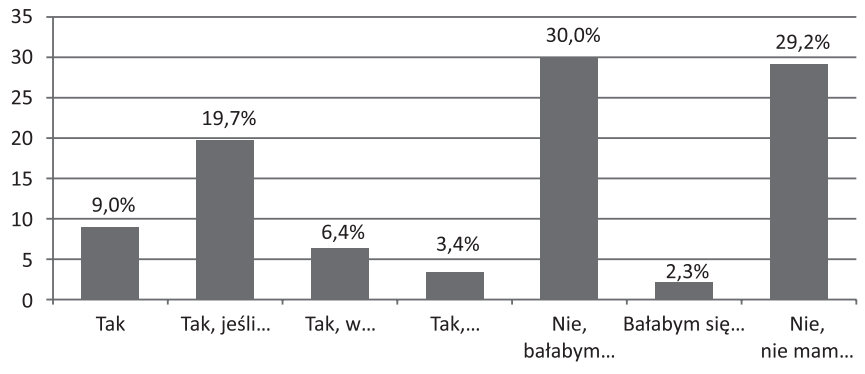

RYCINA 3. Zgoda na poprowadzenie porodu w warunkach pozaszpitalnych

Częstość odpowiedzi była istotnie zależna od wieku $\left(\chi^{2}=37,07 ; p=0,005\right)$, wykształcenia $\left(\chi^{2}=44,23 ; p=0,045\right)$ oraz stażu pracy w warunkach sali porodowej $\left(\chi^{2}=23,07 ; p=0,021\right)$.

Respondentki do 45. r.ż. najczęściej wskazywały na potrzebę współpracy personelu medycznego $(24,2 \%)$, natomiast położne powyżej 46. r.ż. uważały za najistotniejszy czynnik podejście społeczne, które powinno ulec zmianie $(7,8 \%)$. Położne mające do 25 lat częściej niż starsze koleżanki zaznaczały potrzebę wprowadzenia kursów przyjmowania porodów w domu $(5,2 \%)$; 26-35-letnie uczestniczki badania optowały za zwiększeniem świadomości zawodowej, a położne powyżej 46. r.ż. częściej niż młodsze wspominały o zwiększeniu samodzielności zawodowej. 


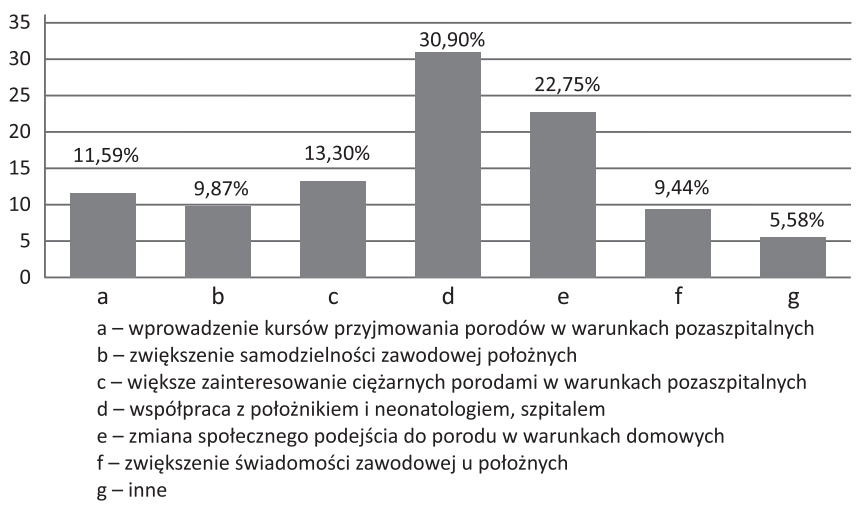

RYCINA 4. Czynniki mogące zachęcić do zajęcia się porodami w warunkach pozaszpitalnych

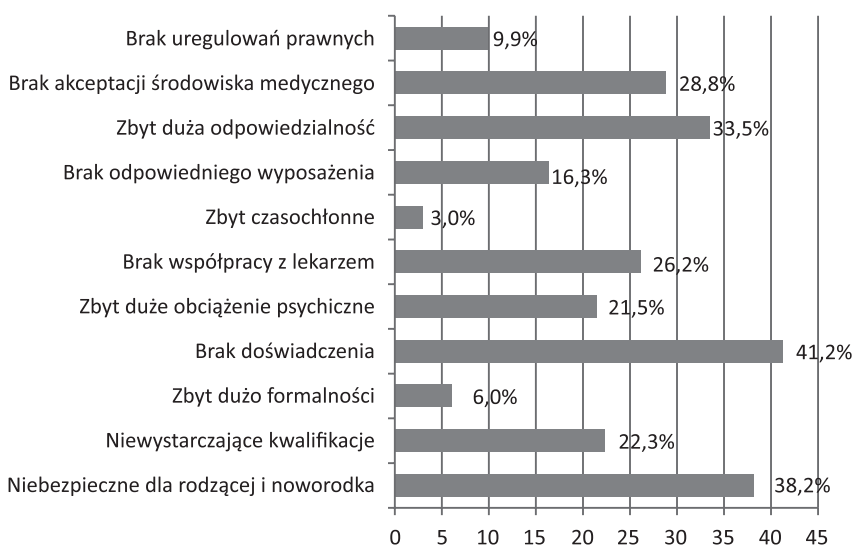

RYCINA 5. Czynniki negatywnie wpływające na decyzję o prowadzeniu porodu w domu

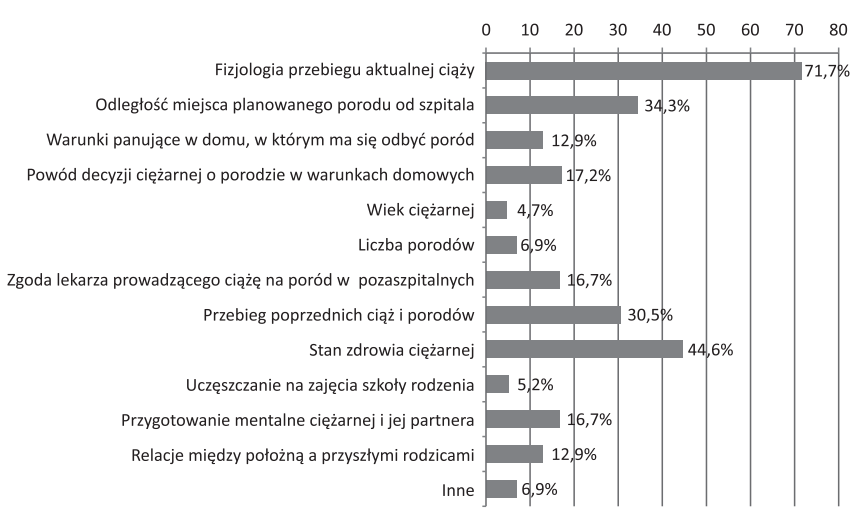

RYCINA 6. Czynniki wpływające pozytywnie na podjęcie decyzji o prowadzeniu porodu w warunkach domowych

Według respondentek najważniejszymi negatywnymi czynnikami wpływającymi na decyzję o prowadzeniu porodu w warunkach pozaszpitalnych były: brak doświadczenia 41,2\%, przekonanie, że mogłoby być to niebezpieczne dla rodzącej i noworodka - 38,2\%, a także zbyt duża odpowiedzialność zawodowa - 33,5\% (ryc. 5).

Spośród najczęściej wybieranych czynników pozytywnych mających wpływ na podjęcie decyzji o prowadzeniu porodu poza szpitalem respondentki wskazywały na fizjologię przebiegu aktualnej ciąży - 71,7\%, następnie na zdrowie ciężarnej - 44,6\% oraz odległość miejsca planowanego porodu od szpitala $-34,3 \%$ (ryc. 6).

\section{DYSKUSJA}

Niezależność zawodowa położnej gwarantowana jest przez art. 6 Ustawy o zawodach pielęgniarki i położnej, a podkreślana przez Rozporządzenie Ministra Zdrowia i Opieki Społecznej z dnia 28 lutego 2017 r. w sprawie zakresu i rodzaju świadczeń zapobiegawczych, diagnostycznych, leczniczych i rehabilitacyjnych, wykonywanych przez położną samodzielnie, bez zlecenia lekarskiego [12]. Ciągle jeszcze obowiązujący w randze Rozporządzenia Ministra Zdrowia Standard Opieki Okołoporodowej (Dz.U. 2012, nr 0, poz. 1100) [8], dotyczący procedur postępowania w opiece nad kobietą podczas ciąży, porodu i połogu o przebiegu fizjologicznym oraz noworodkiem, również zapewnia położnej obszar niezależnego praktykowania, w tym obsługę porodu w warunkach pozaszpitalnych. Według Drużdżel i wsp. [13] położne dobrze znają obszar swojej samodzielności i odpowiedzialności. Jednak większość z nich nie jest skłonna do opieki nad kobietą i jej dzieckiem poza szpitalem. Fryc [14] w badaniach dotyczących samodzielności zawodowej położnych uzyskała podobny wynik. Opinię o autonomii swojej profesji w badaniach Fryc wyraziło łącznie 73,04\% ogółu badanych położnych. Zdecydowana większość respondentek ze stażem pracy 5-15 oraz powyżej 25 lat uważała, że może samodzielnie opiekować się kobietą podczas ciąży, porodu (poza szpitalem) i połogu o fizjologicznym przebiegu (odpowiednio: 73,53\% i 79,41\%). Kołtunowicz i Bączek [15] uzyskali podobne wyniki badań na temat samodzielnego charakteru zawodu położnej wśród przedstawicieli tej profesji. Autorka postawiła wniosek, że w zasadzie położne biorące udział w przeprowadzonych przez nią badaniach czują się niezależne zawodowo.

Odent [16] w swojej książce „Childbirth and the evolution of Homo sapiens" nadmienia o narastającym w krajach wysoko rozwiniętych zjawisku kryminalizowania porodu w warunkach domowych i traktowaniu takiego wyboru rodziców i położnej jako procederu, mimo iż co do zasady procederem przestępczym nie jest, szczególnie w krajach, gdzie poród w domu nie jest prawnie zakazany [17]. Ostracyzm tego rodzaju powoduje niechęć wśród położnych do podejmowania tej formy aktywności zawodowej. Natomiast w razie konieczności transferu rodzącej i/lub noworodka do szpitala nieprzychylność środowiska medycznego może być przyczyną do odwlekania decyzji o udaniu się do szpitala czy wezwaniu zespołu karetki pogotowia.

Większość położnych biorących udział w sondażu (92,3\%) twierdziła, że w Polsce poród w warunkach pozaszpitalnych jest legalny, 7,7\% temu zaprzeczyło, a 4,3\% respondentek dodało, że mimo to porody poza szpitalem odbywają się. Nie stwierdzono istotnych statystycznie zależności od wieku, wykształcenia, ogólnego stażu pracy czy pracy na sali porodowej.

Poród w miejscach alternatywnych dla szpitala za bezpieczny uznało 78,6\% ankietowanych położnych. Z tego 22,8\% 
stwierdziło, że jest nawet bezpieczniejszy od tego w warunkach szpitalnych. Przeciwnego zdania było $8,2 \%$ respondentów, którzy uważali, że poród poza szpitalem jest kaprysem rodziców, którzy niepotrzebnie ryzykują. Zdania na ten temat nie miało 13,3\% (ryc. 2). Wystąpiła istotna zależność od wieku uczestników badania $(\mathrm{p}=0,015)$ w odpowiedziach na to pytanie. Poród w domu za bezpieczny - pod warunkiem, że jest zaplanowany i odbywa się w towarzystwie położnej - uznały przeważnie respondentki w wieku do 35 lat (28,8\%) i powyżej 46 lat (14,2\%). Za bezpieczniejszy uznało go 8,6\% położnych 36-45-letnich, natomiast za niebezpieczny kaprys rodziców uznało go najwięcej położnych powyżej 36 lat $(5,2 \%)$. Spośród respondentek Dziedzic i wsp. [18] poród w domu za bezpieczny uznawały przeważnie położne powyżej 40. r.ż. Natomiast w badaniach tych nie wykazano istotnej statystycznie zależności od wieku ani ogólnego stażu pracy. Wskazano jednak na związek między stażem pracy na sali porodowej a oceną bezpieczeństwa porodu w warunkach pozaszpitalnych. Za niebezpieczny uważały go przeważnie osoby, które nie miały doświadczenia w pracy na sali porodowej. Zaistniał także związek między opinią położnych a ich wykształceniem. Położne mające wykształcenie na poziomie licencjackim w większości przyjmowały taką alternatywę dla porodu za bezpieczną. We wspomnianych badaniach Drużdżel i wsp. $50 \%$ respondentek uważało poród w warunkach domowych za bezpieczny [13].

Położne odpowiadały na pytanie dotyczące potrzebnych sys temowych zmian, które zwiększyłyby aktywność respondentek w opiece nad rodzącą poza szpitalem. Ankietowane najczęściej (30,9\%) wskazywały, że aby zwiększyć chęć przyjmowania porodów w warunkach pozaszpitalnych, należałoby zadbać o współpracę z położnikiem, neonatologiem i szpitalem. Tego rodzaju odpowiedzi pozwalają przypuszczać, że potrzebne są systemowe zmiany w ochronie zdrowia, które pozwolą na zaistnienie tego rodzaju współpracy. Zmiany te jednocześnie powinny niejako wpisać świadczenie opieki w porodzie pozaszpitalnym $w$ funkcjonowanie systemu opieki okołoporodowej w Polsce. W cytowanej już pracy doktorskiej Fryc ankietowane kobiety, wypowiadając się na temat porodu poza szpitalem, uznały w 32\%, że taka opcja jest bezpieczna pod warunkiem, że położna współpracuje ze szpitalem. Ewentualna współpraca położnej przyjmującej porody poza szpitalem w związku z powyższym powinna być usankcjonowana prawnie. Drugą spośród wskazywanych odpowiedzi była zmiana społecznego podejścia do porodu w warunkach domowych $(22,8 \%)$. Za tę zmianę odpowiedzialne jest przede wszystkim samo środowisko położnych, korporacja zawodowa położnych oraz szeroko pojęte przedstawicielstwo na szczeblach rządowych. Zmiana społecznego oglądu zagadnienia, jakim jest poród fizjologiczny, w tym poród domowy, może odbyć się za pomocą kampanii skierowanych do potencjalnych odbiorców, wzmacniania pozycji położnej i edukacji w zakresie korzyści płynących z odbycia porodu drogami i siłami natury. Położne wskazywały także na potrzebę większego zainteresowania ciężarnych porodami w warunkach pozaszpitalnych (13,3\%), wprowadzenia kursów przyjmowania porodów domowych
(11,6\%), zwiększenia samodzielności zawodowej położnych (9,9\%) oraz świadomości zawodowej $(9,4 \%)$ - rycina 4. Częstość odpowiedzi zależała istotnie od wieku respondentek $(p=0,005)$. Respondentki w wieku do 45 lat najczęściej wskazywały na potrzebę współpracy personelu medycznego $(24,2 \%)$, natomiast powyżej 46 lat na zmiany społecznego podejścia (7,8\%). Położne mające do 25 lat częściej niż starsze koleżanki wskazywały na potrzebę wprowadzenia kursów przyjmowania porodów w domu (5,2\%), 26-35-letnie położne były zainteresowane zwiększeniem świadomości zawodowej, a położne powyżej 46. r.ż. częściej niż młodsze wspominały o zwiększeniu samodzielności zawodowej. W zależności od wykształcenia, które było czynnikiem istotnym statystycznie $(\mathrm{p}=0,045)$, najczęściej na potrzebę współpracy z personelem medycznym wskazywały położne z wykształceniem wyższym I ${ }^{\circ}(10,9 \%)$ i II ${ }^{\circ}(13,9 \%)$, najrzadziej z wykształceniem pomaturalnym (5,6\%). Potrzebę zmiany społecznego podejścia do porodów w warunkach pozaszpitalnych zauważyły głównie osoby z wyższym wykształceniem $I^{\circ}(7,4 \%)$ oraz $\mathrm{II}^{\circ}(10,5 \%)$. Niedostateczne zainteresowanie ciężarnych odczuwają głównie respondentki mające wykształcenie wyższe $\mathrm{I}^{\circ}(7,0 \%)$ i $\mathrm{II}^{\circ}(3,9 \%)$. Zależność istotna statystycznie $(\mathrm{p}=0,021)$ zaistniała również odnośnie do pracy na sali porodowej. Wśród respondentów niepracujących na sali porodowej najczęściej pojawiała się opinia o potrzebie współpracy personelu medycznego $(16,5 \%)$, a spośród osób mających doświadczenie na sali porodowej tego zdania było 13,8\% ankietowanych. Potrzebę zmiany społecznego podejścia wyraziło najwięcej położnych mających doświadczenie w pracy na sali porodowej (13,0\%). Osoby, które nie deklarowały żadnego stażu w bloku porodowym $(9,9 \%)$, także dostrzegały konieczność tworzenia zespołów terapeutycznych opiekujących się rodzącą w warunkach domowych.

Położne jako najważniejsze motywy decydujące o podjęciu prowadzenia porodu domowego wskazywały głównie te, które związane były ze zdrowiem ciężarnej i jej historią położniczą. Najczęstsze w związku z tym i najważniejsze wśród respondentek były odpowiedzi dotyczące fizjologicznego przebiegu aktualnej ciąży (71,7\%), stanu zdrowia ciężarnej $(44,6 \%)$, odległości miejsca planowanego porodu od szpitala (34,3\%) oraz przebiegu poprzednich ciąż i porodów (30,5\%) rycina 6. W grupie badanej przez Drużdżel i wsp. [13] położne, które deklarowały chęć prowadzenia porodu domowego, jako czynniki wpływające na tę decyzję wymieniały głównie fizjologiczny przebieg porodu, historię położniczo-ginekologiczną, odległość od szpitala, posiadanie środka transportu oraz relacje z pacjentką i jej partnerem. Wyniki badań przedstawione przez Drużdżel i wsp. [13] w najważniejszych punktach dotyczących bezpieczeństwa medycznego są tożsame z wynikami przedstawionymi w niniejszym artykule.

Z czynników negatywnie wpływających na decyzję o prowadzeniu porodu w warunkach domowych najpopularniejsze były takie, jak: brak doświadczenia respondentek $(41,2 \%)$, możliwość wystąpienia zagrożenia zdrowia lub życia kobiety i dziecka (38,2\%), poczucie ciążącej, zbyt dużej odpowiedzialności (33,5\%), brak akceptacji środowiska medycznego (28,8\%), brak współpracy z lekarzem (26,2\%) oraz niewystarczające 
kwalifikacje samych położnych $(22,3 \%)$ - rycina 5. W przytaczanym badaniu Drużdżel i wsp. położne zwróciły uwagę na te same czynniki, lecz w innej kolejności. Przede wszystkim obawiały się powikłań, obciążenia psychicznego, zbyt dużego ryzyka dla matki i dziecka, a także uważały, że nie mają odpowiedniego doświadczenia. W badaniach Fryc położne (49,57\%) jako największą trudność w samodzielnym praktykowaniu uznały brak świadomości środowiska medycznego w tym zakresie. Wynik uzyskany przez Fryc jest spójny z odpowiedziami lekarzy i pielęgniarek z tegoż samego badania, dotyczącego zakresu samodzielności zawodowej położnych [14]. Pielęgniarki wyraźnie częściej od lekarzy uważały, że położne mają pewien zakres samodzielności zawodowej, odpowiednio: 57 (57\%) oraz 15 (37,5\%) osób. Natomiast lekarze częściej od pielęgniarek wskazywali wariant odpowiedzi „nie wiem” na powyższe pytanie, odpowiednio: 16 (40\%) oraz 17 (17\%) osób. Zaobserwowana zależność miała charakter statystycznie istotny $(\mathrm{p}<0,05)$. Niski stan świadomości, szczególnie lekarzy, w zakresie samodzielności zawodowej położnych może skutkować trudnościami w uzyskaniu odpowiedniej pomocy i obniżać bezpieczeństwo matki (i/lub dziecka), która zdecydowała się na poród poza szpitalem.

W Polsce nie są prowadzone oficjalne badania statystyczne dotyczące przebiegu zaplanowanego porodu domowego. Również roczniki demograficzne Głównego Urzędu Statystycznego nadal nie wyodrębniają miejsca porodu jako domu [19]. W związku z tym nie jest dostępna wiedza na temat liczby zaplanowanych porodów w towarzystwie położnych odbytych w domu. Wszystkie porody, które odbyły się poza szpitalem - bez względu na przyczynę - są klasyfikowane jako poród w innym miejscu z pomocą fachową lub bez niej. Jednakże jest istotna różnica w przebiegu między planowanym porodem domowym z asystą medyczną a przypadkowym tego rodzaju zdarzeniem. Stowarzyszenie Niezależna Inicjatywa Rodziców i Położnych, które zrzesza samodzielnie praktykujące położne z obszaru całej Polski, publikuje coroczne statystyki dotyczące planowanych porodów w warunkach domowych. W latach 2010-2015 odbyło się 630 porodów rozpoczętych i zakończonych w domu w asyście położnych. Poza tym 105 porodów rozpoczętych w wymienionym przedziale czasowym zostało przeniesionych z różnych powodów z domu do szpitala. Na uwagę zasługuje liczba ciężarnych - 383 kobiety, które zostały przez położne w tym okresie zdyskwalifikowane z możliwości odbycia porodu w warunkach domowych [20]. Prawidłowo przeprowadzona na podstawie np. SOO kwalifikacja ciężarnej do porodu w domu w dużym stopniu może obniżyć ryzyko okołoporodowe.

Opinia położnych na temat planowanego porodu w warunkach domowych może się diametralnie zmienić. Zależy to od pojedynczych osób wykonujących ten zawód, środowiska i korporacji zawodowej położnych, polityki państwa w tym obszarze i zapotrzebowania na tego rodzaju opiekę wśród kobiet. Istotnym elementem w zmianie obrazu porodu w warunkach domowych jest także prowadzenie oddzielnych statystyk i badań w tej odrębnej dziedzinie opieki okołoporodowej. Wyniki badań mogłyby być publikowane, dyskutowane, a w efekcie dawałby rzetelną wiedzę i podstawę do budowania systemu ochrony zdrowia, w którym położna, rodzice i poród w warunkach pozaszpitalnych mieliby swoje integralne miejsce. Tego rodzaju analizę przebiegu porodu domowego i porównanie wyników uzyskanych w stosunku do porodów szpitalnych prowadzi wiele państw. W 2009 r. opublikowano badania prowadzone w Kolumbii Brytyjskiej w Kanadzie porównujące przebieg zaplanowanych porodów z niskim ryzykiem okołoporodowym w domu z porodami szpitalnymi, w których także występowało niskie ryzyko. Wyniki tych badań dały pozytywny obraz porodów prowadzonych przez położne w warunkach domowych. Śmiertelność noworodków na 1000 urodzeń wynosiła 0,35 w domach, a w porodach szpitalnych 0,57. Podobne wyniki uzyskano w zakresie opieki nad kobietą. Badacze wnioskowali na podstawie przeprowadzonych przez siebie badań, iż poród w domu w towarzystwie położnej był korzystniejszy niż w szpitalu z obecnością położnej lub lekarza [21]. Wyodrębnienie w badaniach statystycznych zaplanowanego porodu domowego dałoby szansę na uzyskanie odpowiedzi, jaki przebieg owe porody mają w Polsce i czy rzeczywiście wiążą się z tak wielkim zagrożeniem dla matki i dziecka. Rezultaty takich badań zainicjowałyby też dyskusję w tej dziedzinie, oparty na rzetelnych danych, a nie historycznych doniesieniach czy prywatnych poglądach medyków.

\section{WNIOSKI}

1. Położne biorące udział $w$ badaniach miały wiedzę, że w Polsce poród w warunkach pozaszpitalnych jest legalny.

2. Respondentki potwierdziły, że położna może samodzielnie sprawować opiekę nad kobietą w ciąży, podczas porodu i połogu fizjologicznego w warunkach pozaszpitalnych.

3. Chęć zajmowania się opieką nad rodzącą w warunkach domowych była zależna istotnie od opinii własnej na temat porodu poza szpitalem.

4. W celu zwiększenia liczby położnych przyjmujących porody w warunkach domowych, należałoby stworzyć podstawy prawne współpracy między tymi położnym a szpitalem i personelem lekarskim.

5. Istnieje potrzeba edukacji przeddyplomowej i podyplomowej położnych oraz innych pracowników medycznych, a także upowszechniania informacji na temat kompetencji położnych i ich możliwości prowadzenia porodów w warunkach pozaszpitalnych.

\section{PIŚMIENNICTWO}

1. Smerdka. A. Samodzielność i kompetencje zawodu położnej w systemie podstawowej opieki zdrowotnej w Polsce. Pol Prz Nauk Zdr 2015;42(1): 45-50.

2. Urbanek B, editor. Zawód położnej na ziemiach polskich w XIX i XX wieku. Katowice: Śląska Akad. Med.; 2004. p. 267.

3. Matuszewska E. Zarys historii zawodu położnej. Warszawa: Rea; 2012.

4. Rozporządzenie Prezydenta Rzeczypospolitej z dnia 16 marca $1928 \mathrm{r}$. o położnych. http://dziennikustaw.gov.pl/du/1928/s/34/316 (23.06.2017). 
5. Ustawa o zawodach pielęgniarki i położnej z dnia 15 lipca 2011 r. (Dz.U. $2011 \mathrm{nr}$ 174, poz. 1039).

6. Piórkowska M. Pielęgniarstwo - rzemiosło czy profesja? Mag Pielęg Położ 1998;5:6-7.

7. Bączek G. Położna - zawód samodzielny. Położ Nauka Prakt 2007;1:24-7.

8. Rozporządzenie Ministra Zdrowia z dnia 20 września 2012 r. w sprawie standardów postępowania medycznego przy udzielaniu świadczeń zdrowotnych z zakresu opieki okołoporodowej sprawowanej nad kobietą w okresie fizjologicznej ciąży, fizjologicznego porodu, połogu oraz opieki nad noworodkiem (Dz.U. 2012 poz. 1100).

9. Dzierżak-Postek E, Grzybowska K, Krauze M, Oleś K, Romanowska M, Witkiewicz M. Model opieki nad kobietą i dzieckiem w fizjologicznym okresie okołoporodowym w praktyce pozaszpitalnej. Położ Nauka Prakt 2010;4:8-19.

10. Tanday S. Midwife-led units safest for straightforward births. National Institute for Healt and Care Excellence. https://www.nice.org.uk/news/ article/midwife-led-units-safest-for-straightforward-births (03.07.2017).

11. Tymiński R. Status prawny położnej - kompetencje i odpowiedzialność, możliwości. VIII Ogólnopolski Zjazd Szkół Rodzenia. Międzyzdroje, 7-10.10.2008.

12. Rozporządzenie Ministra Zdrowia z dnia 28 lutego 2017 r. w sprawie rodzaju i zakresu świadczeń zapobiegawczych, diagnostycznych, leczniczych i rehabilitacyjnych udzielanych przez pielęgniarkę albo położną samodzielnie bez zlecenia lekarskiego Na podstawie art. 6 ustawy z dnia 15 lipca 2011 r. o zawodach pielęgniarki i położnej (Dz.U. 2016, poz. 1251,
1579 i 2020) http://g.ekspert.infor.pl/p/_dane/akty_pdf/DZU/2017/47/497. pdf\#zoom=90 (03.07.2017).

13. Drużdżel M, Dmoch-Gajzlerska E, Doroszewska A. Samodzielność i odpowiedzialność zawodowa w opinii współczesnej położnej na podstawie badań własnych. Położ Nauka Prakt 2007;1:28-31.

14. Fryc D. Kompetencje zawodowe położnych w świetle ustaw i rozporządzeń polskich. Zapotrzebowanie społeczne na opiekę okołoporodową sprawowaną przez położne [dissertation]. Szczecin: Pomeranian Medical University in Szczecin; 2012.

15. Kołtunowicz M, Bączek G. Samodzielność położnych. Mag Pielęg Położ 2005;5:36.

16. Odent M. Childbirth and the evolution of Homo sapiens. London: Pinter \& Martin Ltd; 2014.

17. Sarnacka E. Położna w systemie prawnym. Warszawa: PZWL; 2012.

18. Dziedzic M, Matuszyk D, Prażmowska B. Poród domowy w opinii położnych VIA Medica. http://czasopisma.viamedica.pl/pp/article/ view/23189/18415 (15.07.2015).

19. Rocznik Demograficzny GUS. Warszawa: GUS; 2016. p. 301.

20. Niezależna Inicjatywa Rodziców i Położnych. Statystyki 2010-2015. http:// www.dobrzeurodzeni.pl/statystyki.html (03.07.2017).

21. Janssen PA, Saxell L, Page LA, Klein MC, Liston RM, Lee SK. Outcomes of planned home birth with registered midwife versus planned hospital birth with midwife or physician. CMAJ 2009;181(6-7):377-83. doi: 10.1503/cmaj.081869. 